\title{
Aeschylus' Oresteia and the Problem of the Tragic Nature of Man \\ Lukáš Jeník
}

\begin{abstract}
The significance of the ancient tragedies is still relevant. Their constant inspiration for education lies, among other things, in their contribution to the issue of finding the essence of human nature. Aeschylus' work is one of the key milestones in literature, but it is also an example of the formation of specific (non-philosophical) answers to the question of man and his essence. The aim of the analysis of the trilogy Oresteia is to present selected aspects of this thinking which reflects and foreshadows problems in the philosophy of the $5^{\text {th }}$ century BC. The study also focuses on the instrumental value of tragedy. Tragedy (not systematically, but more effectively and suggestively) represents one aspect of human nature - homo tragicus. Aeschylus' answer to the question of human nature is also related to his emphasis on the importance of law and justice which should be the only ruler in the community.
\end{abstract}

Keywords: Aeschylus, tragedy, human nature, polis

Even in Classical Antiquity, theatre and drama were instruments and ideological spaces, as specific ethical ideas and political ideals were introduced through them to the audience. Thanks to the theatrical performance and its suggestive effect on the audience, the members of the polis were effectively formed and inspired. ${ }^{1}$ However, the question of justice was present in Greek culture before the creation of works of classical tragedies. Even ancient myths, such as those written by Homer and Hesiod, reflect forms of pre-philosophical legal reasoning on the issues of law, justice, and virtue. ${ }^{2}$ However, in the period after the Greco-Persian wars, there was a significant political transformation of Greek society, and this ideological and political turn influenced and used the art of theatre and drama in state propaganda. The art of poetry, drama, and theatre not only responded to this social transformation, but also catalysed the mentioned processes of transformation and aided their social acceptance. ${ }^{3}$

Theatre and drama, in tragedies or comedies, have been and often are a projection screen of social

1 Representatives of classical ancient theatre (tragedy and comedy) are characterised by the penetration of social and political themes into their work, and thus by the education of virtue. This old-fashioned ideal disappeared in the $4^{\text {th }}$ century BC. This also led to conservative theoretical reflections which were exemplified by Aristotle. Cf. also Nurit YAARI, Greek Tragedy in Theory and Praxis: Aristotle's Theory of Tragedy in the Perspective of Aristophanes' Theatre Practice, Maske und Kothurn 1/1989, pp. 7-19. Cf. also Jaroslav DANEŠ, Politické aspekty řecké tragédie, Červený Kostelec: Pavel Mervart, 2012, pp. 13-29.

2 Cf. Rastislav NEMEC, Filozofia práva I. Od Homéra po Augustína, Trnava: Dobrá kniha, 2017, p. 12.

3 Cf. Thomas A. SZLEZÁK, Za co vděčí Evropa Řekům, Praha: Oikoymenh, 2014, pp. 151-162. 
change and social criticism. ${ }^{4}$ However, an equally important aspect of Greek tragedy is the existence of a tragic hero - an individual whose identity and nature is determined by a tragic context. Regardless of the anthropological significance of theatre, ancient drama itself presents to us the general contribution of the culture of tragedy and drama to the debate on human nature even before philosophy. For prosaic reasons, this aspect of the view of human nature is not something that appears automatically in drama theory. The first systematic thinking theorist of tragedy and theatre, Aristotle, stopped understanding theatre as a performance in the modern anthropological sense, an echo of the ritual world, a world where the profane and the sacred meet. He sees tragedy as an effective tool that cleanses the excess of the passions. This trap, into which Aristotle draws all his followers due to his authority, influenced the understanding of theatre theory and tragedy until the postmodern theatre period. ${ }^{5}$ Jean-Pierre Vernant emphasises that

tragedy emerged in Greece at the end of the sixth century. Within a hundred years the tragic seam had already been exhausted and when Aristotle in the fourth century set out, in his Poetics, to establish the theory of tragedy, he no longer understood tragic man who had, so to speak, become a stranger. ${ }^{6}$

It is precisely the tragic nature of human existence that ancient drama teaches us and for which it continues to be relevant today. The tragedies that stem from interpersonal relationships are no different from the problems of today's man. As Alessandro D'Avenia points out, the essence of tragedy is the current presence of tragic choices only. We cannot escape them, and we have to choose. ${ }^{7}$ This aspect goes beyond the perspective of Aristotle's thinking about tragedy as an activity that mediates only catharsis. At the same time, Vernant implicitly emphasises the present conflict of ancient theatre and drama as one paradigm of the education of and discussion about human nature with the advent of the philosophy of Socrates, Plato, and finally Aristotle. ${ }^{8}$ In the ancient playwrights, the authors of tragedies and comedies, we reflect on those concepts and problems that we encounter in the works of contemporary and later philosophers, but also in the whole spectrum of humanistically oriented psychology and pedagogy. ${ }^{9}$

But why should we focus on the work of ancient playwrights, when problems that are only hinted at in tragedies are solved in the field of philosophy more systematically and more precisely? After all, it is philosophy which gives us answers to the question about man. An analysis of Aeschylus'

4 Cf. Charles SEGAL, Divák a posluchač, in: Ǩecký člověk a jeho svět, ed. Jean-Pierre VERNANT, Praha: Vyšehrad, 2005, pp. 183-185. According to Segal, several socially critical problems can be clearly identified in tragedies. We can mention a few: gender issues (examples are Aeschylus' Oresteia, Euripides' female heroines like Medea or the Bacchae), the idealisation of a rational ruler (King Oedipus by Sophocles), criticism of tyrannical and wayward ways of governing or violent politics (The Trojan Women by Euripides). The ancient tragedy, the text of the drama or comedy as well as the theatrical performance are a reflection of the problems of the polis. Segal emphasises that it was a tragedy that 'was able to symbolically develop contemporary debates on major moral and political issues on stage' (p. 183).

5 Cf. Florence DUPONT, Aristoteles alebo upír západného divadla, Bratislava: Divadelný ústav, 2016. For a more detailed analysis of the concept of catharsis and, implicitly, on the controversy with Dupont's opinion, see Martin ŠARKAN, On the issue of the concept of catharsis in Aristotle's theories of tragedy and drama, Studia Aloisiana 4/2016, pp. 63-78.

6 Jean-Pierre VERNANT, Tensions and Ambiguities in Greek Tragedy, in: Myth and Tragedy in Ancient Greece, eds. Jean-Pierre VERNANT and Pierre VIDAL-NAQUET, New York: Zone Books, 1990, p. 29.

7 Cf. ( ) Alessandro D’AVENIA, Oreste o del futuro, in: Corriere della sera / Ultimo banco (on-line), available at: https://www.corriere.it/ alessandro-d-avenia-ultimo-banco/19_settembre_16/2-oreste-o-futuro-315cab68-d791-11e9-9016-c6193fcbf5c4.shtml, cited $8^{\text {th }}$ June 2020.

8 Cf. VERNANT, Tensions ..., pp. 32-48. Martha C. Nussbaum explicitly addresses this issue. She points to the relationship between ethical concepts in tragedies that deal with randomness and thus with the tragedy of human destinies. Cf. Martha C. NUSSBAUM, Křehkost dobra : Náhoda a etika v řecké tragédii a filosofii, Praha: Oikoymenh, 2003, pp. 56-90.

9 Cf. Martin ŠARKAN and Rastislav NEMEC, Humanistic Paradigms of Education in the Postmodern Vision, in: Journal of Pedagogy 2/2010, pp. 99-119. 
selected work reveals that, in addition to myth, the world of ancient drama and theatre has the ambition to answer such a question. Contrary to philosophy, however, the world of drama is much more effective. The reach of art, doubted by Plato, was and still is much greater than the words of a philosopher. Regardless of this tension, art and philosophy are united by the effort to reflect on reality. The subject of the following parts of the text is an analysis of Aeschylus' trilogy Oresteia. This work - albeit a tragedy framed by ancient myth - shows the artist's ambition to answer questions which are typical of philosophy: what causes human misery - tragedy - and what is the key to the ability to face it.

The fate of its heroes illustrates the playwright's pre-philosophical examination of the existential situation of man (free/unfree), his nature (rational/irrational), and the meaning of his existence (social creature). ${ }^{10}$ These selected areas represent a context that frames the question of human nature not only for Aeschylus, but for Sophocles and Euripides as well. ${ }^{11}$

\section{Aeschylus and the Freedom of Subjects}

Regardless of the debate on the development of tragedy and the comparison of individual works, their content, and formal specifics in the classics of ancient tragedy, it can be said that Aeschylus is the first of the great playwrights whose work contains practical conflict. The term was coined by Martha C. Nussbaum, and she defines it as follows: 'Greek tragedy shows good people being ruined because of things that just happen to them, things that they do not control. This is certainly sad; but it is an ordinary fact of human life, and no one would deny that it happens.' ${ }^{12}$ Since Aeschylus, the Greek tragedy has taught us to deal with this fact which cannot be solved by faith, nor by intellectual analysis.

This practical conflict is the already mentioned essential motif of tragedy which is not defined so suggestively in any ancient culture. For comparison, there is the exclamation of the Jewish prophet Jeremiah (Jer 17:5-8) which is an example of contrast thinking. The Greek tragedies and the prophetic exclamation of Jeremiah are a reflection of two different cultures and religious beliefs. Jeremiah emphasises the direct causality between human will, human free choice, and subsequent action and the will of God who lets these tragic trials happen. For a believing Jew and later a Christian, however, this situation of letting something happen is linked to purpose. Unhappiness is always interpreted with regard to providence and justice, and thus hope. ${ }^{13}$ The purpose of the misfortune encountered by biblical figures such as Job or Jeremiah is to convert the sinner, respectively the demonstration of providence. God blesses or punishes according to the situation, that is, an individual either behaves or not in accordance with the covenant. However, there is no trace of such an intended purpose in ancient drama and tragedy. There are simply tragedies. They have no purpose; they do not lead to any knowledge of transcendence which overlaps tragedy and gives it meaning. In addition to the banality of evil, we have the banality of tragedy. However, this

10 Discussing human nature at the moment of the turning point in Greek culture is not only a broader philosophical-literary problem, but also a living philosophical problem to this day. The problem of nature is framed by the extreme positions of essentialism with the postulate of unchanging nature and the opposite position of extreme social constructivism. Between these two positions, there is room for discussion about, so to speak, the hard core of immutable characteristics and the coverage that forms the variable and cultivable characteristics. On this issue, see Miroslav KARABA and Rastislav NEMEC, Človek medzi prírodou, kultúrou a technikou: vybrané reflexie problému ludskej prirodzenosti, Trnava: Dobrá kniha, 2018.

11 I would like to thank the reviewers for their inspiring and constructive comments. These helped me to improve the work, outline other perspectives for research, and point out the absence of serious titles on the topic.

12 NUSSBAUM, Křehkost..., p. 93.

13 Cf. George STEINER, Smrt tragédie, Bratislava: Divadelný ústav Bratislava, 2011, pp. 7-10. Cf. also NUSSBAUM, Křehkost..., pp. 139141. 
motif, which is fully expressed especially in Sophocles' work, can be seen in Aeschylus' and Euripides' work. It characterises their thinking about human nature, about man as a homo tragicus. The tragedy of human existence is not something distant in a historical point of view. On the contrary, tragicism and related positions such as Kafkaesque absurdity or bizarreness are, as D’Avenia suggests, a natural part of everyday life. ${ }^{14}$ This is the core of suggestiveness and the effect of tragedies depicting practical conflict. ${ }^{15}$ Classical works, such as tragedies, are as close to existential questions as works of modern literature, because the author and the reader are the same subject - man. They depict experience in the form of works of art which cannot be paraphrased. The effectiveness of these works not only supports our imagination. The dramas show the story of one type of generalisable human experience to the performance viewer or the text reader. Subjective experience becomes a part of the whole spectrum of one set of experience - the experience of man and his existence. The range of historical answers to this existential starting point (whether we understand tragic practical conflict as a way-out without the end or, vice versa, as something that has a solution) can be found in various philosophical-anthropological, religious-spiritual, and ethical theories.

According to Erika Fischer-Lichte, Aeschylus (525/524-456/455 BC, the first of the classical ancient playwrights) and his work present the birth of what can be described as a dramatic expression of the ideal of emerging and future polis and related circumstances. In the case of Aeschylus' tragedies, the practical conflict of tragic heroes, who decide between different tragic choices, is set in the context of thinking about justice. Naturally, this leads to questions: what does justice have to do with the character of human nature, and in what sense can art teach us about this practical conflict?

\subsection{The Hero as a Free and Fair 'Slave' of the Polis}

Tragedy originates in the fate of the human being. Despite this burden of slavery and the lack of freedom, Aeschylus uses the space of his drama to build the ideal of a being who faces the slavery of predestination, curses, and destiny. Such a being acts with tragic consequences, but his actions are typically human. At the same time, Aeschylus outlines a space in which it is possible to moderate and partially eliminate the impact of tragedy. It is a justly administered polis.

Oresteia is an example of the connection between the subject of tragic conflict and the context of the debate on justice. ${ }^{16}$ It is a trilogy that consists of several separate dramatic units. They contain

14 'Lessenza della tragedia è infatti dover decidere tra opzioni ugualmente senza speranza, come in uno degli scatti più drammatici dell'11 settembre, nel quale vediamo un uomo lanciarsi nel vuoto pur di non bruciare vivo: The falling man. Anche noi, a volte, ci sentiamo così e scegliamo ciò che in quel momento ci sembra il male minore.' ( D’AVENIA, Oreste...

15 Cf. NUSSBAUM, Křehkost..., p. 138. Like Steiner, Nussbaum works with the intuitive assumption that practical conflict is present not only in ancient tragedies, but also in everyday life. But why is this phenomenon becoming the subject of direct and indirect criticism which ultimately leads to the death of tragedy? The difference between Hellenic, Semitic and later Christian culture is a hypothesis which is too general, and, according to Nussbaum, the death of tragedy stems in Greek culture itself - in philosophy. The beginning of the death of tragedy is the gradual birth of the intellectual dominance of philosophy and the emphasis on systematic solutions. Practical conflict without a solution is the exact opposite of the thinking of Socrates, Plato, or Aristotle and its direction. Such thinking seeks and offers noetic values: truth and certainty. The philosophical search carries within itself an optimistic assumption of hope. It allows one to hope that the tragic circumstances of human existence can be overcome, or avoided. However, this is not a hope in the sense of faith. This hope springs from a philosophical consideration of assumptions related to human nature. Cf. Rastislav NEMEC, O nádeji z filozofického hladiska, Viera a život 3/2013, pp. 75-79.

16 Cf. Erika FISCHER-LICHTE, Dejiny drámy, Bratislava: Divadelný ústav, 2003, pp. 19-30. Oresteia was performed in 458 BC. Like Fischer-Lichte, Goldhill emphasises that the understanding of Athenian democracy, the phenomenon of public holidays, and the role of theatre (as a medium which shapes the citizens and their community) is the context and lens through which Oresteia should be interpreted. Aeschylus' dramatic work supports and at the same time uses all the above factors. Theatre becomes a source of promotion of the ideal of the polis as a democratic community in which the institutions of law guard justice. The village and its unifying rituals are 
one specific myth, namely the genesis and history of the curse of Atreus' house or family. ${ }^{17}$ The trilogy consists of Agamemnon, The Libation Bearers, and Eumenides. ${ }^{18}$

Concerning form and content, Aeschylus bases his work on traditional epics and the art of poetry. However, his elaboration of older mythological stories is, in many ways, paradigmatic. The search for the nature of law (nomos) and the ideal of justice (diké), which one already finds in Hesiod or Homer, is clearly present in Aeschylus' tragedies as well. However, unlike older myths, his work is enriched with specific details which are not only for formal decoration, but, on the contrary, serve to explicitly point out what the playwright wants to emphasise. Regardless of the interpretation itself, these details can be recognised and reflected upon. Details concerning, in particular, the spread of the Atreus myth divert the mythical story (as presented in the older literature) and promote new political social solutions to conflicts. ${ }^{19}$ His work is characterised by original formal elements such as dramatic dialogue, a noble type of recital, and the introduction of the character of the second actor. This brings a radical formal novelty into the theatre performance. ${ }^{20}$ However, something more important than form is reflected in his work. To understand the Greek culture of the late $6^{\text {th }}$ and $5^{\text {th }}$ centuries BC, but also to understand the already mentioned problems of human nature, the political context seems to be the key factor.

Aeschylus wrote his work at a time when one era of political and social development of Greek culture was coming to an end and another was just beginning. With the end of the Greco-Persian wars, trade flourished. As a financial aristocracy had been arising, finances no longer accumulated in the hands of the families. With his tragedies, the playwright reflects Heraclitus' view that life is a struggle in which there is a constant transformation of opposites. ${ }^{21}$ The monarchical and oligarchical establishments based on the families ended their development at that time. ${ }^{22}$ The value of equality and the rule of equals also characterise the aristocratic-oligarchic elite, but the democratically oriented current is dominated by a more general and horizontal understanding of the ideal of equality (isonomy). Vernant points out that in the $6^{\text {th }}$ century $\mathrm{BC}$, there is a radical change in the understanding of the ideal of equality. Before that time, it was understood in the narrower political context of the ruling aristocracy. The change consists in the fact that the ideal of equality was not reflected in the idea of equality of 'more equal' only, that is, aristocracy, but it shows itself in the equality of all, more widely understood free people. This change is the result of complex social and cultural relationships. One of them, though, is prosaic and symbolically reflects the radicality of change. It is about democratising the military and transforming military strategy.

During the $8^{\text {th }}$ and $7^{\text {th }}$ centuries $\mathrm{BC}$, there was a strategic economic and social transformation of the army and the associated demanding capital expenditures for the cavalry, a significant component of the military strategy of the monarchy and aristocracy. While in the older way of leading

also a social space in which the individual fulfils his freedom, meaning, and political identity in the best way. Cf. Simon GOLDHILL, Aeschylus - The Oresteia, Cambridge: Cambridge University Press, 2012, pp. 7-11.

17 Cf. Encyklopedie antiky, ed. Ludvik SVOBODA, Praha: Academia, 1973, pp. 90-91.

18 Cf. Encyklopedie antiky, p. 176.

19 Cf. George THOMSON, Aischylos a Athény, Praha: Nakladatelství Rovnost, 1952, pp. 255-256. Thus, Aeschylus' elaboration does not only mention the motif of the conflict of laws and justice, which also frames older myths as a theme, his change also concerns what he sees as a means of finding justice and law. The theatre plays with a mythical theme, thus reflects quite natural political and philosophical views on how to seek justice and laws. 'In der Orestie hat Aischylos aufgezeigt, dass das menschliche Urverlangen nach individueller Gerechtigkeit, wenn irgendwo in der Geschichte, so nur in einem wohlgeordneten Staatswesen realisierbar ist.' Walter NICOLAI, Zum doppelten Wirkungsziel der aischyleischen Orestie, Heidelberg : Universitätsverlag Winter, 1988, p. 54.

20 For the key importance of Aeschylus' dramatic techniques, cf. Eva STEHLÍKOVA, Antické divadlo, Praha: Karolinum, 2005, pp. 55-58.

21 On this issue, cf. Ferdinand STIEBITZ, Aischylova Oresteia, in: Oresteia, AISCHYLOS, Praha: Artur, 2014, pp. 196-236.

22 Cf. THOMSON, Aischylos..., pp. 211-229. 
armed conflicts, horses and chariots dominated as a symbol of political power, in the period of the $7^{\text {th }}$ and especially the $6^{\text {th }}$ century BC, there was a significant transformation of combat strategy, namely a strategic emphasis on infantry and more effective phalanx manoeuvres. During the Greco-Persian conflicts, this type of fighting proved to be an effective response to the demands of both defence and attack. An economically cheaper and militarily more effective way of fighting, which was tested not only in regional conflicts but also in the clashes of the Greco-Persian wars, became a source of equality not only on the battlefield and during the war, but also within the village in peacetime. ${ }^{23}$

According to Vernant, Homer's Achilles, dragging Hector's corpse around the walls of Troy, was a hero whose actions were no longer valuable in the time of Aeschylus. This way of military heroism ended not only at the moment of the transformation of military strategy, but also hand in hand with the transformation of ancient Greek society in the $6^{\text {th }}$ century BC. The new ideal of heroism and the virtuous warrior was a man in heavy armour bravely fighting for the survival or glory of the polis. This is the opposite of the individualistic heroism of mythical warriors who were subject to greed and pride (hybris). The hoplite, who did not come from an aristocratic family, was recruited from the free citizens of the city, and was the owner of his own armour, was the exact opposite of the mythical hero, whose aristocratic origin itself bore the mark of nobility. The hero of the real battlefield rejected individualism, and his survival and victory were the victory of the whole phalanx. He was aristocratic - noble and courageous - not by his origin, but by the nobility of ideals that transcend individuality. What was desirable in the new warrior was no longer stubborn passion (thymos) or the pride (hybris) which springs from it. The preferable elements were moderation and deliberation (sófrosyné). The new hero was characterised by 'perfect self-control, the ability to submit to a common discipline, coolness suppressing instinctive tensions that could disrupt the order of formation. ${ }^{24}$

The heroes of the trilogy, by their will to act justly or unjustly, are subject to or resist pride. They become part of the set of consequences which have an impact not only on them, but on the whole community, and the situation can be solved in the context of the polis itself only.

Aeschylus was the first of the great playwrights dealing with the ideology of the polis. He promoted those ideals of equality. The sanctity of such ideals guaranteed the survival and prosperity of any community. The context of the conflict of different ideas about the form of justice, which results in a practical conflict, provided him with a space for thoughts. In it, he corrected and moderated the consequences of bad decisions, and, at the same time, he emphasised the ideals that define tragic human nature.

Man in any of his tragic moods, chooses and acts within his community. This is his nature and it is only thanks to community and being within it that he is destined to be free, and at the same time he really is. ${ }^{25}$

23 The formation of hoplites armed with relatively unified armament, which consisted of a large shield (hoplon) and a spear, was effective precisely because of its ability to close up and manoeuvre as a whole. The heavy armament of soldiers limited individualism on the battlefield and naturally led to an emphasis on the effectiveness of collective manoeuvring. The combat unit, armed with long spears, marching while protected by a wall of shields, represented a developmental leap of the military art. On the mentioned issues of the origin of the Greek phalanx and its significance in the context of building a Greek polis, cf. Jon E. LENDON, Soldiers and Ghosts: A History of Battle in Classical Antiquity, New Haven; London: Yale University Press, 2005, pp. 39-90. For a comprehensive overview of the current state of the discussion on the hoplite reform, cf. also Gregory F. VIGGIANO, The Hoplite Revolution and the Rise of the Polis, in: Men of Bronze: Hoplite Warfare in Ancient Greece, eds. Donald KAGAN and Gregory F. VIGGIANO, Princeton; Oxford: Princeton University Press, 2013, pp. 112-133.

24 Jean-Pierre VERNANT, Počátky řeckého myšlení, Praha: Oikoymenh, 1993, pp. 44-45. On this issue, cf. also LENDON, Soldiers..., p. 62.

25 Cf. Miroslav KARABA, Sme slobodní alebo neslobodní?, in: Viera a kultúra cestou človeka, ed. Miloš LICHNER, Trnava: Dobrá kniha, 2017, pp. 301-324. Ancient man is not a kind of causa sui that is freed from other determining causes, but quite the opposite. A curse 


\subsection{Curse of Fate or Choice of Curse?}

The key idea of Aeschylus' trilogy is that the consequences of some kind of choice and action not only affect the actor himself, but change the order of things and disrupt the justice of the community. The actions of the heroes are not separated from the existence of the community. This is why the polis is able to correct the tragic nature of human existence. ${ }^{26}$

But are the heroes free, or are they just pieces on the chessboard of destiny? If they are acting freely, what does the free choice that leads to the tragic event stem from? Aeschylus realises that the drama which his heroes rush into lies in their misjudgement, blindness, sinfulness, or simply it is the will of the gods. Each of them decides and chooses on the basis of external and internal circumstances. Although the idea that we are a toy in the hands of the gods is contrary to our idea of the relationship between freedom and justice, it is connected with the understanding of the relationship between the gods and man in ancient religion and also with the meaning of freedom. ${ }^{27}$ The will of the gods, or any transcendent cause beyond our ability to explain and justify it, is, so to speak, synonymous with the inexplicable tragedy of human destinies. One can only resign oneself and accept the fact that a given destiny is something which one cannot break free from. However, this frustration of ancient man, who lives under the weight of destiny, does not diminish personal responsibility and the limits of human freedom within the restricted possibilities provided by curses or gods. In this tragic situation, which transcends the limits of our rationality or the idea of absolute freedom, Aeschylus - like Sophocles later - tries to illustrate the key idea to the spectator. This one stems from the connection between religion and morality.

According to Stiebitz, the tragic conflict and misfortune - sent by the gods to the individual heroes of the tragedies who are seen by us, the readers and the spectators - serve to educate the hero and man in general and to improve one's morality. ${ }^{28}$ The will of the gods and the justice of this will are in many ways an incomprehensible secret to man, but it still gives direction. Considering the debate on piety, Aeschylus adds something that transcends the external form of religiosity.

Even though a person's destiny is unstable, and the gods often intervene in it with their motivations which we do not know, one must be able to make the right decision and accept destiny as a challenge. He must seek the most just decision and must act in accordance with divine justice. But how to know justice in the confusion of gods' desires and traditions that refer to gods' laws? What characterises Aeschylus' work on the outside is the conflict of the concepts of justice and obedience to the law. These are sometimes determined by tradition (duty of vow) and at other times by a specific god. ${ }^{29}$ Are these justifications in conflict which will be resolved by rational reasoning? Is it a conflict between a better and a worse concept of justice? Contrary to the hypothesis that this is logically inconsistent internal conflict in which several conceptions of justice (diké) compete, and which for some interpreters of the trilogy is evidence of the imperfection of form or rather the beginnings of the development of dramatic literature), Martha C. Nussbaum offers an alternative interpretation. ${ }^{30}$

or other formal form of the influence of destiny represents what we might call, using the modern Popperian term, metaphysical determinism. The relationship between determinism and freedom understood in this way, which, however, does not exclude the moral responsibility of a person for his actions, was already known in ancient philosophy.

26 Like Steibitz, Nussbaum emphasises the importance of the community as a tool that can purify or stabilise corrupt or tragic human nature. Cf. NUSSBAUM, Krehkost..., p. 127.

27 Cf. STIEBITZ, Aischylova..., p. 202. Cf. also Eric R. DODDS, Řekové a iracionálno, Praha: Oikoymenh, 2000, pp. 53-69.

28 Cf. STIEBITZ, Aischylova..., p. 204. Cf. also NUSSBAUM, Křehkost..., pp. 139-141.

29 Cf. NUSSBAUM, Křehkost..., pp. 93-103. Cf. also Jean-Pierre VERNANT, The Historical Moment of Tragedy in Greece: Some of the Social and Psychological Conditions, in: Myth and Tragedy in Ancient Greece, eds. Jean-Pierre VERNANT and Pierre VIDAL-NAQUET, New York: Zone Books, 1990, pp. 23-28.

30 Cf. NUSSBAUM, Křrehkost..., pp. 95-96. 
Martha C. Nussbaum sees the supposed logical inconsistency as a positive motive, not a mistake. She sees this element, which others perceive as a formal imperfection, as an intuitive expression of a tragic practical conflict. Several controversial concepts are contradictory only if there is a dichotomous taxonomy on the basis of which one choice is clearly good and the other bad. In Sophocles' Antigone, for example, there is a relatively clear conflict of justice. Namely, it is the requirement of obedience to the law of the community governed by Creon and the requirement of piety and obedience to the divine law that Antigone chooses to follow.

Regardless of the in-depth analysis, the dichotomy of the demands of justice is clearer in Sophocles and is primarily seen as an interpretive key in the case of some of Aeschylus' heroes. Agamemnon's guilt for killing his daughter also seems clearer than the mitigating circumstances he is defending. ${ }^{31}$ But what about obedience to two laws which have divine origin and are explicitly required by a god? And how to act in a situation which his son Orestes is in? This is not a formally inconsistent literature, but a truly unsolvable problem of the conflict between the law of revenge and the law of 'conscience'. Orestes must decide between competing demands of which legitimacy is given by the gods themselves. The duty to a god and to the law or the murder of the mother. That is a dilemma!

\subsubsection{Orestes - an Example of a Tragic Hero}

For Aeschylus, it is the specific choices and subsequent actions of the hero that trigger the practical level of tragic conflict. In general, and from the point of view of the value of religiousness (eusebia), everyone who does evil must also suffer. The act of evil brings a natural need for reaction, and evil cannot remain without retribution. ${ }^{32}$ However, Aeschylus brings the theme of the moral dilemmas which the young hero must face at several levels. His problem begins with the murder of his father, his mother's husband and the king. This act seeks revenge. However, the murder of the king, father and husband, is only an imaginary beginning. The assassination of Agamemnon was brought about by a series of causes that make his killing not only a murder stemming from his wife's personal transgressions, but also the necessary updating of the curse on his family. Orestes faces the duty to avenge his father by punishing the murderers and the dilemma of murdering his own mother.

Aeschylus portrays the actors of the tragedy as beings facing more or less unsolvable dilemmas. They stand between the freedom not to obey an order or divination and the obligation to obey a request that stems from tradition, divination, etc. Their decisive obedience leads to another part of their fate. Clearly, these demands are presented as dilemmas of justice. However, free choice seems to be in contrast with the fate of the curse over the whole family which stands behind it. None of the heroes is free in the sense in which we understand free human actions, because every hero of the trilogy and his actions appear to be another link in the chain of curses. In absolute terms, everyone is determined, and he just updates the potential for a curse. ${ }^{33}$ Is this determination

31 If we place Agamemnon's guilt in the broader context of the myth, his case also seems tragic and unsolvable in many ways. Dodds emphasises the religious reason for Agamemnon's defence and his choices and actions. Given this context, Agamemnon's practical conflict seems much more burning and unsolvable. Cf. DODDS, Řekové..., pp. 11-35.

32 'Justice turns the wheel. "Word for word, curse for curse be born now," Justice thunders, hungry for retribution, "stroke for bloody stroke be paid. The one who acts must suffer." Three generations strong the word resounds.' Robert FAGLES and William Bedell STANDFORD, The Oresteia: Agamemnon, The Libation Bearers, The Eumenides, Penguin Classics, 1984, p. 192. In Czech, AISCHYLOS: Obět na hrobě, in: Oresteia, AISCHYLOS, Praha: Artur, 2014, pp. 95-96.

33 This meta-narrative in the background of the trilogy is also an impetus for the victimisation of actors. Nussbaum, using the analysis offered by, for example, Dodds, Lesky, and Lloyd-Jones, illustrates the conflict between the fate of Agamemnon, who kills his daughter Iphigenia at the behest of Zeus, and his personal choice - so to speak, by his alibi-like surrender which makes him guilty. NUSSBAUM, 
an attenuating circumstance that mitigates their guilt? However, Aeschylus does not think in this way and does not ask this question. The first critical point is the ambition to solve the unsolvable. Aeschylus is aware of the determination of the curse that hangs over his heroes and heroines. The curse of the family is synonymous with tragic nature as the starting point of human existence. However, it does not matter what the fate of the actors is. The key is their decision at a time which, so to speak, has no solution.

The second critical point is the critique of the very way in which they act and the position they hold after the emergence of this conflict. At the level of their lives, there is a discrepancy between their actions, which are determined by the circumstances, but also by an intuitively understood idea of justice. This idea is contrary to what they perceive as an obligation to the gods. Nevertheless, they consciously violate a certain type of moral imperative, being orders that are just (not to kill a daughter, not to kill a husband, not to kill a mother). Tragic nature then results precisely from the fact that they choose the supposed solution over the insolvability of tragedy.

Each of the heroes, Agamemnon, Clytemnestra, and their son Orestes, act with the knowledge that they will suffer. Each of them is intuitively aware of the dilemma between objective norms and subjective desire. Even if their choice is supported by divine will, this still applies. In order to be able to march with his army to Troy, Agamemnon kills his daughter. He knows he should not do it, but he does it. ${ }^{34}$ His wife Clytemnestra kills the returned tyrant, her lawful husband and rightful ruler. Using the act of revenge, she hides her own infidelity. ${ }^{35}$ Revenge for the daughter's death and subjective motivations - jealousy and infidelity - are stronger than the fear of killing a husband and king. The female heroine also assures herself that her right to revenge is fair. After it, facing her son's revenge, she does not hesitate to defend herself using the fact of predetermination of ancestral curse. One murder follows another, and the trilogy of revenge is completed by the son of Agamemnon and the Clytemnestra - Orestes. He kills his mother without this intention and punishes the murderer which is the act he desires to do.

Agamemnon justifies his decision to sacrifice his daughter by emphasising obedience to the divination which makes it possible to fulfil the demand for revenge and punishment. ${ }^{36}$ However, the cause of the sacrifice of the daughter is not the divination itself. This is only a means of making peace with the goddess and thus of one type of justice. The reason is the obedience of the ruler to his people, the obligation to punish the betrayal of one Trojan prince, etc. However, Agamemnon accepts the yoke of necessary obedience to the law of tribe and family fanatically and without any fight, as evidenced by the singing of the choir. ${ }^{37}$ What makes the monarch guilty is, so to speak, that he avoids taking responsibility for his choice to sacrifice his daughter with the imperative of the law. The King solves the tragic conflict by cynical thinking, that is, he tells himself: when the various choices are all tragic, why not finally choose the one that is more beneficial ${ }^{38}$ The death of a daughter is less of a loss than the loss of the opportunity to conquer Troy and fulfil the obligation to punish disgrace. After all, the reasons for his choice are the ones which usually determine his actions - passion and pride. The internal justification for obedience to the command is thus not

Křrehkost..., pp. 109-126.

34 Cf. AISCHYLOS, Agamemnón, in: Oresteia, AISCHYLOS, Praha: Artur, 2014, p. 15.

35 About the nuances and the debate on the blood curse and Aeschylus' work, cf. STIEBITZ, Aischylova..., p. 207.

36 'And once he slipped his neck in the strap of Fate, his spirit veering black, impure, unholy, once he turned he stooped at nothing, seized with the frenzy blinding driving to outrage - wretched frenzy, cause of all our grief! Yes, he had the heart To sacrifice his daughter, To bless the war that avenged a woman's loss, A bridal rite that sped the men-of-war.' FAGLES and STANDFORD, The Oresteia, p. 110. In Czech, AISCHYLOS, Agamemnón..., p. 15.

38 Ibid, p. 15. 
based on piety, which would not solve anything anyway, as obedience should respect both types of laws, which are inherently divine in origin. The way how Agamemnon justifies obedience, on the other hand, is a caricature of piety that obscures his passionate irrational surrender. Regardless of the moral assessment that is the subject of constant debate, the dilemma of the two demands of justice (diké) is still the framework of the tragedy.

Unlike his father, Orestes is in an even more complicated situation. According to Martha C. Nussbaum, the playwright underlines the basic hypothesis of the insolvability of practical conflict using Orestes and his situation. ${ }^{39}$ Orestes is aware of the dilemma of the laws of the family and the natural doubts to which this legal obligation is directed. Like his father, he is aware of the practical conflict. Unlike his father, though, he has no lateral motivations, such as the obligation to punish treason and gain fame by conquering Troy. He is not driven by ambition or pride (hybris). The resolution of the practical conflict in the case of Agamemnon led to an update of the curse, but also to the heroic fate of the conqueror of Troy. In the case of the son, the conflict is framed by the avenging (his father) and the murder (his mother). The tragedy captures how the son ponders the decision to avenge his father through the murder of his own mother. ${ }^{40} \mathrm{He}$ perceives murder as a spoil. It does not make him a famous winner like in case of his father; it is just the opposite. ${ }^{41}$ From the beginning of the second part of the trilogy, he realises that he is sent to act in the name of a god, and to act in a very difficult task - to be the murderer of his mother. ${ }^{42}$ The execution and subsequent awareness of the act leads him to what the chorus declares: none of us can live without being affected by tragic conflict. At every moment of a tragic decision, however, Aeschylus emphasises the autonomy of choice, but also some uncertainty in the decision. However, the guilt and punishment, which each of the heroes of the trilogy is aware of, are the consequences which they accept in the name of subjective demands. They freely choose to be determined, and the curse, which was said a generation ago, continues. They know the curse that results from breaking the law. And yet, they make indirect decisions in favour of it. ${ }^{43}$

The identity of each of the actors of the tragedy is tied to the blood and the tribe. ${ }^{44}$ It is a predisposition that individuals carry with them. They are determined by a curse, but their actions are always their choice. So, it is their choice that will allow them to remain in this curse. Their free choice is confirmed by their mythical genetic code; their bloody origin is at the source of the curse. Their decision will actually bring them into a cursed community. Individual characters are even aware of their identity, where it goes, and how they fulfil it. It is freedom that is blinded by personal motives or ancient laws of the family which the new polis seeks to change. Against such thinking, Aeschylus sets the point of his trilogy which culminates in the Eumenides. ${ }^{45}$

The tragedy of the curse of the family, which is reinforced by the choice of each participant, is broken by divine intervention at the end of the whole drama. ${ }^{46}$ Against the identity and nature of

39 Cf. NUSSBAUM, Křehkost..., p. 140.

40 Cf. AISCHYLOS, Obět..., pp. 120-129. In the dramatic dialogue between son and mother lies the key point of the dispute between the laws of the family, the natural doubts, and remorse over the mother's death. One of the extended hands of the divine, and the embodiment of erroneous will at the same time, is Orestes' friend Pylades. He points out the unquestionability of the fact that the originator of the command of revenge is the divine Apollo.

41 Orestes states at the moment of reflection at the end of the game: 'Look, the blood ran here, conspired with time to blot the swirling dyes, the handsome old brocade. Now I can praise you, now I am here to mourn. You were my father's death, great robe, I hail you! Even if I must suffer the work and the agony And all the race of man - I embrace you ... you, My victory, are my guilt my curse, and still -' FAGLES and STANDFORD, The Oresteia, p. 223. In Czech, AISCHYLOS, Obět..., p. 126.

3 Ibid., p. 126.

44 Cf. FISCHER-LICHTE, Dejiny..., pp. 19-20.

45 Cf. GOLDHILL, Aeschylus..., pp. 24-33.

46 Cf. THOMSON, Aischylos..., pp. 286-308. 
the person who is subjected to the curse stands a new possibility - the identity of the citizen of the polis. In Eumenides, Athena intervenes and appoints a new arbitrator of justice, a court within the community. With her vote, she advocates for the last hero of the trilogy to be pardoned. ${ }^{47}$ However, the entry of Athena is more than just a symbolic entry of wisdom.

Other gods appear in the drama as well. It is Apollo who advises Orestes to kill his mother. Paradoxically, Orestes' mother is not persecuted for the murder of her husband and his father, but Orestes is. It is the Erinyes, an older generation of gods, who persecutes the hero. However, both divine parties in the dispute over Orestes, that is, the god who inspired it and also the goddess of revenge, are wrong. This is why the input of another divine entity is different and refers to a different conception of justice. Aeschylus, emphasising piety, speaks of the entry of a goddess who symbolises something more than that which was previously considered divine ${ }^{48}$ Athena symbolises not just wisdom. By her actions she represents true piety in practice - the righteousness of wisdom. The figure of the goddess in this tragedy symbolises the 'principle of the polis'. ${ }^{49}$ Athena does not resolve the conflict in terms of support for one of the parties in the dispute. She does not even agree with Apollo, who is a symbol of Zeus, Athena's father. She does not agree with the Erinyes either. Those call for compliance with the law which restore the viability of the community. Athena establishes a court consisting of people, not gods. The practical conflict of heroes has led to tragic consequences, so Athena, using her position, moderates this conflict by emphasising missing elements, and by emphasising the elements which have led everyone to fateful tragedies. She emphasises moderation as such (sófrosyné). ${ }^{50}$

Aeschylus is not concerned with repealing the law of retribution, with tradition as such. He wants the formal anchoring of punishment in the court process, which no longer understands punishment as a wayward act of retaliation, but gives it legally objective legitimacy. Objectivity is born of piety, moderation, and abstention, because where one sees a solution, Aeschylus sees an intractable tragic conflict. The court appointed by the goddess is thus a symbol of the legal rejection of the sudden revenge. It is a wayward punishment that is carried out as if in the name of justice, but it is not legitimate. A punishment imposed by a court is legitimate. It is the court and the judicial power, that is, the third party, that decides fairly. Here, too, Aeschylus surprises by gradually building tension. For the last hero, the tragedy turns out well. However, the aeropagus - the judiciary - does not free him from his guilt. ${ }^{51} \mathrm{He}$ is democratically judged. The divine intervention of Athena then helps to lift the curse of punishment, as her voice is the one that prevails in favour of innocence.

Of course, the question arises as to whether it is possible to speak of justice when Orestes is justified by a single vote? Is the court, which is the result of a democratic vote, also fairer? During the trial, the Erinyes blamed the accused Orestes and the god Apollo who sent him to murder his mother on the basis of a divination. In their speech before the court, they emphasise the impact which release, that is, the avoidance of punishment, would have on the community. To set a murderer free is against divine laws. Aeschylus realised the meaning of this symbol. If the Erinyes were goddesses who punished bloody murders, perjured oaths, etc., how could one reject their opinion? The Erinyes themselves point to the essential, the justice of the divine laws. These must be the source of any written or unwritten human law. But this dispute between the law

47 Cf. THOMSON, Aischylos..., p. 288.

48 Cf. FISCHER-LICHTE, Dejiny..., pp. 26-30. Cf. also THOMSON, Aischylos..., pp. 288-289.

49 FISCHER-LICHTE, Dejiny..., p. 26.

50 Cf. THOMSON, Aischylos..., p. 292.

51 Cf. FISCHER-LICHTE, Dejiny..., p. 30. 
or the will of Apollo and his prophecy and the Erinyes cannot be settled justly in favour of one party or the other. This is the essential idea or underlining point. Fairness between option A or B cannot be established. This is not because there is a third possibility, but because the morality of divine conflicts and de facto erroneous divine decisions (the imperfect divination of one god and selective activity of punishing done by the Erinyes, who punish just the son but not the mother) is not a righteous morality, and therefore it cannot be truly divine. The goddess, a symbol of wisdom, legitimises the law of the community and the judicial tribunal. They are both placed above older traditions and the will of the gods. It is an aeropagus that has the right to punish but also to forgive. Its divine establishment is the beginning of a morality of which the ideal of justice is above the chaos of blood and ancestral ties. ${ }^{52}$ After all, the goddess herself also appeases the punishing goddesses. They are entitled to punish, but the playwright portrays their justice as selective and in fact unjust. They punish and demand punishment for the son, but they did not punish the mother who had murdered as well. Athena, as a symbol of wisdom and objectivity, also transcends Apollo's divine power and places a new synthesising element between the two divine powers (Apollo and the Erinyes) - the polis and its institution of the aeropagus.

\section{Conclusion}

The tragic fate of ancient heroes is not only a distant literary memory. In the work of Aeschylus, Sophocles, and Euripides, this problem acquires its specific formal expression, which is inspiring not only for philosophy, but also for education. The specific fate of ancient heroes is not that important here, as it is more about the practical conflict which leads them to tragedy, and it resonates in the everyday personal tragedies of contemporary man as well.

Man in Aeschylus' work appears to be subject to the fate of a curse or to the duties of a family and deities. The frustrating situation in which ancient heroes (not only in Aeschylus' work) find themselves is the cause of the choices that lead to a tragic situation. However, the tragic nature of life cannot be perceived as absurd. The hero does not face tragedy as something that does not make sense. This question is absent in ancient tragedy. The hero faces tragedy as something with an unknown meaning. It cannot be clear to us either. This is why we are all obliged to face tragedy in the best possible way even more.

The challenge of facing the tragic consequences of one's actions is also linked to the reflection of their origins and their causes. Here is outlined the second perspective of thought that Aeschylus is aware of. Although his heroes are cursed and their decisions are given by a curse or other heteronomous cause, it is more or less their autonomous decision that updates their curse potential. In his trilogy, Aeschylus presents a paradigmatic anthropological observation - a practical tragic conflict. As Martha C. Nussbaum points out, not only in ancient drama but also in everyday experience, 'we find, instead, a complex spectrum of cases, interrelated and overlapping in ways not captured by any dichotomous taxonomy. ${ }^{53}$ The idea of a practical conflict that leads to tragedy is a type of experience, universal and timeless. That tragic nature of human existence, our empathy with others in their own tragic situation and the associated compassion, converge with each other over time. This can be seen as an inspiration not only for education but also for raising children. Aeschylus' response to the tragedy is not philosophical in the sense of seeking certainty and means to overcome the tragedy. However, it is not religious either. Otherwise, it would perceive the

52 Cf. THOMSON, Aischylos..., pp. 297-298.

53 NUSSBAUM, Krehkost..., p. 101. 
experience of a tragedy with hope. The world of tragic art is a far more sceptical and - one might say - more realistic approach. The literary work carries an instrumental value. On the one hand, it teaches us about the tragic nature of being, but on the other hand it shows Aeschylus' specific attitude towards the situation as he wants to find space for growth in a tragic destiny. Tragedy has the potential to immunise our rational reflection on the tragedy of everyday life, without the prospect of faith and hope.

The question arises: how does it immunise human existence against the reach of tragedy? Paradoxically, it is a reflection upon the existence of man as a person who is endowed with the intellectual nature and pro-sociability which he develops in community. It is the nature of man as a social and rational being in which Aeschylus' ancient hero finds the source of strength to face an insurmountable obstacle, to face the consequences of the tragic nature of his being. Although the tragedy remains, and the grief of the heroes and spectators (who in everyday lives represent the actors of their own tragedies) does not diminish, the example of the heroes clearly shows the way how to accept a tragic existence into one's life, how to be prepared for it, and filter the values which one follows. Tragicism is rationalised and its consequences are eased and carried by the whole polis. The final part of the tragedy also reveals the importance of society and the culture of law. This influences human nature and cultivates its natural talents.

Aeschylus' trilogy shows the content connection of two areas, the problematisation of which we find in the ancient philosophy of man and no less in current debates. The question of human nature and its rationality (rational in Aeschylus and Sophocles, subject to the passion of Euripides) cannot be separated from the problem of justice. It is precisely in the search for justice and submission to the law where human dignity reflects itself. The human ability to face tragedy with dignity and not succumb to the passions stems from a rational nature that recognises and reflects upon the practical conflict leading to tragedy. Whatever the fate of man is, mitigation is possible only in the community, because it is ultimately a community that is affected by the misfortune of the individual. The polis, which is governed by the law (nomos) and by the search for justice (diké), is (for both Aeschylus and Sophocles) a space in which the individual can mitigate, but not negate, the consequences of practical conflict. The emphasis on the polis as a space of law and justice, which is consciously incorporated into Aeschylus' dramas, is later explicitly expressed in Plato's and Aristotle's political philosophy and ethics; and a well-managed polis becomes a medium in which the individual is allowed to reach for bliss.

\section{Contact:}

\section{Dr Lukáš Jeník}

Trnava University in Trnava

Faculty of Theology

Department of Christian Philosophy

Kostolná 1, 81499 Bratislava

lukas.jenik@truni.sk 